\title{
Twenty-Six CLR Fellows Will Undertake Varied Projects in 1975-76 as Members of Council's Seventh Class
}

The Council on Library Resources (CLR) Fellowship Committee has selected twenty-six librarians and other professionals working directly with libraries as members of the seventh class of CLR fellows.

Commencing in the fall of 1975, the new CLR fellows will launch three- to nine-month, self-developed study or research projects in areas ranging from computer-based reference service in academic libraries to the administration of rare book and special collections departments in large public university libraries. Other representative project areas include church libraries, nineteenth-century American architectural periodicals, academic libraries' middle management, nonsexist subject headings, censorship of nonbook media in public libraries, and external degree programs.

There exists an equally wide range in titles and responsibilities among the twenty-six new CLR fellows. In addition to librarians of varied responsibilities from colleges and universities, there are others serving special, public, and military libraries and a professional staff member of the American Library Association.

In making the twenty-six new awards at an estimated cost of $\$ 80,000$, the council raises to 165 the number of CLR fellows announced since the program was begun six years ago. Including commitments to the seventh class of CLR fellows, the council has authorized in excess of a half million dollars for the program.

As in previous years, CLR fellows will receive funds for approved travel, supplies, and services from the council and an appropriate leave of absence from their employers to carry out their projects.

Applications for the fellowships were first reviewed by a screening committee of eight eminent librarians-Mary E. Corning, assistant director, International Programs, the U.S. Department of Health, Education, and Welfare; Elizabeth Hage, director, Prince George's (Md.) County Memorial Library System; Roy Land, director of circulation services, the University of Virginia; John Lorenz, acting Librarian of Congress; A. P. Marshall, dean of academic services, Eastern Michigan University; Stephen McCarthy, retired executive head of the Association of Research Libraries, Annapolis, Md.; Carlton Rochell, director, Atlanta Public Library; and Esther Walls, director of the library, State University of New York at Stony Brook.

Final selections were made by the council's
Fellowship Committee: Louis B. Wright, vicechairman of the CLR Board of Directors and director emeritus of the Folger Shakespeare Library, chairman; William S. Dix, librarian of Princeton University; Robert Vosper, professor of library science, University of California at Los Angeles; and, ex-officio: Fred C. Cole, president; Foster E. Mohrhardt, senior program officer; and Edith M. Lesser, secretary and treasurer, all of CLR.

The Council on Library Resources, Inc., is a private operating foundation which, through directly administered programs as well as grants to and contracts with other organizations, seeks to aid in the solution of problems of libraries generally and of academic and research libraries in particular. The council was established in 1956 with support from the Ford Foundation from which it continues to derive its funding.

The twenty-six recipients of Council on $\mathrm{Li}-$ brary Resources fellowships for the academic year 1975-76 and their projects are as follows:

Judith Armstrong, director of the library, Drury College (Mo.). Survey of attitudes, employment practices, and the progress of affirmative action programs for women in libraries.

Pauline Atherton, professor, School of Information Studies, Syracuse University. A survey of the real and potential impact of computerbased reference service in academic libraries.

Martha J. Bailey, physics librarian, Purdue University. A study of the position of the middle manager in the academic library organization.

Boyd M. Bolvin, associate dean of instruction, Bellevue Community College (Wash.). An examination of external degree programs in higher education in the U.S.

Keith $M$. Cottam, assistant director of the Undergraduate Library, University of Tennessee at Knoxville. A study of the issues involved in the utilization of specialists in large academic libraries with emphasis on technical specialists.

Doris C. Dale, associate professor, Department of Instructional Materials, Southern Illinois University at Carbondale. To gather data and information about community college libraries for a book on current trends and practices and to enrich her background for courses taught in this area.

Lynn C. Dennison, professional assistant, Association of College and Research Libraries, American Library Association, Chicago. To 
gather information on organizational patterns in library and media services in community and junior college libraries and to evaluate these patterns in terms of their usefulness in meeting information needs of users.

Barbara L. Feret, director of the library, Culinary Institute of America, Hyde Park, N.Y. To survey, identify, and analyze strengths of important historically oriented collections on gastronomy and cookery.

Thelma Freides, associate professor, School of Library Service, Atlanta University. Preparation of a bibliographic guide to the reports which officials of the federal government are required to submit to Congress.

Wolfgang $M$. Freitag, fine arts librarian, Harvard College Library, Harvard University. To complete work on and prepare for publication a manuscript of about 150 printed pages for "Sources of Information in the Humanities."

Jane C. Henning, head, Howe Architecture Library, Arizona State University at Tempe. A study of libraries associated with schools of architecture in the United States.

Judith Holliday, librarian, Fine Arts Library, Cornell University. To complete a holdings list of the nineteenth-century American architectural periodicals.

Richard G. Landon, assistant head, Thomas Fisher Rare Book Library, University of Toronto. A study of the administration of rare book and special collections departments in large public university libraries.

Alan H. MacDonald, health sciences librarian, Dalhousie University (Halifax, N.S.). To study the various organizational models which universities have adopted to accommodate the "special" circumstances of professional school libraries.

James W. McGregor, head of the library's technical services, Northeastern Illinois University. To study staffing for serials processing in large university libraries.

Joan K. Marshall, chief of the library's Cata$\log$ Division, Brooklyn College. The construction of a thesaurus of nonsexist subject headings.

Ann F. Painter, professor, Graduate School of Library Science, Drexel University. To determine the functions of traditional library classifications in research libraries in the United States.

James F. Parks, Jr., head librarian, Millsaps College (Miss.). To carry out an internship at the Georgia Institute of Technology.

Stephen L. Peterson, divinity school librarian, Yale University. To do basic research for a bibliographic guide to protestant missions.

Eugene E. Petriwsky, assistant director for the libraries' technical services, University of Colorado. To study the effect of proposed changes in the eighth edition of the Library of
Congress List of Subject Headings on mediumsized academic libraries.

Hannelore B. Rader, orientation librarian, Eastern Michigan University. To study ten successful library instruction programs in academic libraries and summarize findings in the form of a guide.

Donald L. Roberts, audiovisual librarian, Hennepin County Library, Edina, Minn. To examine past and present censorship of nonbook media in public libraries.

Earl R. Schwass, library director, Naval War College (Newport, R.I.). To study user education programs of senior military and graduate school libraries with particular reference to the needs of midcareer military officers.

Patricia H. Shoyinka, cataloger, Ibadan University Library, Ibadan, Nigeria. To study the use of MARC records for catalog production in selected North American libraries in order to determine basic criteria for the use of MARC records in Nigeria.

Mildred C. Tietien, director of library services, Georgia Southwestern College. To compare and evaluate instructional programs at ALA-accredited graduate library schools.

Joyce L. White, librarian, Penniman Library of Education, University of Pennsylvania. To organize available information on church libraries in order to produce a reference tool on church libraries.

\section{Oboler Plans A (nother) New Library for Idaho State}

A new library building for Idaho State University (Pocatello, Idaho), to include 160,000 square feet, and to cost $\$ 7,200,000$ with furnishings and landscaping, will be built at the center of the campus, beginning in the summer of 1975. The Idaho legislature added $\$ 3,300,000$ to the $\$ 2.5$ million appropriated in 1974, and, according to University Librarian Eli M. Oboler, the $\$ 5,800,000$ will suffice to build the basic building, with the fourth floor left unfinished-to be funded within the construction period, it is hoped.

Mr. Oboler is in the unusual, if not unique, position of having planned two complete academic library buildings on the same campus, a generation apart. The first building, 77,000 square feet, was built and furnished for $\$ 750,000$ in 1953-54. The new building will also include the audiovisual facilities for the university. 